\title{
Interannual variation in diets of walleye pollock in the Doto area, in relation to climate variation
}

\author{
Orio Yamamura ${ }^{1, *}$, Tetsuichiro Funamoto ${ }^{1}$, Masayuki Chimura ${ }^{1}$, Satoshi Honda ${ }^{2}$, \\ Tatsuki Oshima ${ }^{3}$
}

\begin{abstract}
${ }^{1}$ Hokkaido National Fisheries Research Institute, Fisheries Research Agency, Kushiro 085-0802, Japan
${ }^{2}$ National Research Institute of Fisheries Science, Fisheries Research Agency, Yokohama 236-8648, Japan

${ }^{3}$ Marine Fisheries Research and Development Center, Fisheries Research Agency, Yokohama 220-6115, Japan
\end{abstract}

\begin{abstract}
Interannual variation in the diet of walleye pollock Theragra chalcogramma along the southeastern coast of Hokkaido Island (Doto area) was analyzed using >15 000 specimens collected in the periods 1989-1992 and 1995-2011, in relation to oceanographic variables. The area experienced a warm period from 1998 to 2002, which was preceded and followed by cold periods. An apparent shift in diet occurred between the first cold period and the warm period. Appendicularians (larvaceans) became an important summer prey for small-sized pollock ( $\leq 300 \mathrm{~mm}$ SL) in addition to copepods and euphausiids, which were also important before the onset of the warm period. In medium- and large-sized pollock, an abrupt decrease in mesopelagic fishes (mainly myctophid Diaphus theta) was observed in stomach contents $3 \mathrm{yr}$ after the 1997/1998 climate regime shift, possibly reflecting a recruitment failure of $D$. theta. Appendicularians, cannibalism and anchovy Engraulis japonica compensated for the disappearance of mesopelagic fishes from the diet. During autumn and winter, a similar shift from micronekton (mainly $D$. theta and firefly squid Watasenia scintillans) to euphausiids (exclusively Euphausia pacifica) and cannibalism was found between 2000 and 2001. Although diet changes lagged the onset of the warm period, condition factor increased immediately after the regime shift. This inconsistency may be attributable to the bioenergetic response of juvenile pollock, which attain better growth at warmer temperatures. Thus, in the Doto area, the effect of climate variation on the survival of pollock seemed to be limited, due to their flexible feeding behaviors.
\end{abstract}

KEY WORDS: Diet shift $\cdot$ Climate variation $\cdot$ Cannibalism $\cdot$ Appendicularians $\cdot$ Diaphus theta

\section{INTRODUCTION}

Walleye pollock Theragra chalcogramma (hereafter 'pollock') is a benthopelagic gadid species distributed throughout the subarctic North Pacific Ocean, extending from Korean waters to the northwestern coast of the USA (Bailey et al. 1999). In addition to being a target of one of the world's largest fisheries (FAO 2009), pollock plays an important role as a forage fish and as an intermediate predator in marine ecosystems due to its widespread distribution and high abundance. Besides being an important prey for demersal fishes and marine mammals
(Springer 1992, Tamura et al. 1998, Yamamura \& Nobetsu 2012), its feeding impact has the potential to deplete local prey abundances (Ciannelli et al. 2004, Wilson et al. 2009). Numerous studies have examined the food habits of pollock throughout its range, describing geographical, ontogenetic and seasonal variations in diet (Dwyer et al. 1987, Gorbatenko \& Dolganova 1989, Yamamura et al. 2002, Wilson et al. 2011). These studies show that pollock feed almost exclusively on pelagic prey, and that the main prey items shift, with growth, from mesozooplankton to forage fishes, including mesopelagic fishes and juvenile pollock (cannibalism). Feeding is largely oppor- 
tunistic, thus variation in diet may be used as a proxy for the prey field in the environment.

The Oyashio is a western boundary current of the subarctic circulation flowing southwest along the Kurile Archipelago and the southern coast of Hokkaido Island. The Oyashio area, characterized by cold temperatures and nutrient-rich water, supports one of the most productive fisheries in the world (Taniguchi 1999, Sakurai 2007). Similar to other areas in the subarctic North Pacific Ocean, this area has been subject to changes in the physical environment resulting in variations in production at the lower trophic levels (Chiba et al. 2008, Tadokoro et al. 2009). In addition to 2 major regime shifts that occurred in the last 50 yr (1976-1977 and 19881989; Hare \& Mantua 2000), a minor shift has been detected in 1997-1998 (Overland et al. 2008). The 1997-1998 shift resulted in warmer temperatures in the surface layer of the Oyashio area for a relatively short period of 5 yr (Ishizaki 2007, Kasai \& Ono 2007), during which above-average primary production was observed every year except 2000 (Okamoto et al. 2010). Sea surface temperatures in the Oyashio area then shifted to a short cold period from 2003 to 2006, followed by years of instability in the physical status (Ishizaki 2011). Such variability may impact higher trophic levels via bottom-up controls. In particular, the population dynamics of pollock could be severely affected because of their prominent cannibalistic behavior (Yamamura 2004, Mueter et al. 2006), making juveniles more vulnerable to predation during years of reduced prey supply. On the Eastern Bering Sea shelf, the abundance of large zooplankton (Calanus marshallae and euphausiids) declined abruptly during a period of warm temperatures (2002-2005). This decline caused dietary shifts in juvenile and adult pollock to small copepods and cannibalism, respectively, and resulted in poor recruitments of pollock due to high overwintering mortality (bottom-up control) and predation (top-down control) (Coyle et al. 2011, Hunt et al. 2011). We expect similar effects of climate variation to occur in pollock in the Oyashio area. Therefore, we analyzed diets and body condition of pollock over $21 \mathrm{yr}$ off the southeastern coast of Hokkaido Island (Doto area) to support the development of a conceptual model relating pollock population dynamics to environmental variability. Data from the first half of this study were previously used to describe general diets of pollock in this area (Yamamura et al. 2002). Here, we compare pollock diets from different periods in relation to environmental variability.

\section{MATERIALS AND METHODS}

\section{Sample collection}

Pollock were collected in the Doto area from 1989 to 1992, and from 1995 to 2011 (Fig. 1). Whereas 'summer' samples (see 'Materials and methods: Data analysis' for definition) were available throughout both collection periods, 'winter' samples were only available from 1995 to 2007. Of the 15482 fish examined, the vast majority were sampled by bottom $(9527 ; 61.5 \%)$ and midwater $(4864 ; 31.4 \%)$ trawls during acoustic surveys on research vessels (Table 1). In addition, 684 $(4.4 \%)$ and $295(1.9 \%)$ specimens were sampled from commercial fishing vessels by bottom trawl and gillnet, respectively, and $112(0.7 \%)$ specimens were sampled from research vessels by hook and line fishing. Although fishing depths (measured as the position of the head rope for midwater trawls, and as bottom depth for other gears) ranged from 25 to 507 $\mathrm{m}$, the greatest portion $(74.8 \%)$ of the sample was captured within the 100 to $250 \mathrm{~m}$ depth zone. The target depth for midwater trawls was generally determined by monitoring the echosounder to sample the densest section of the scattering layer. Water temperatures at fishing depths were recorded using conductivity-temperature-depth probes (CTDs), salinitytemperature-depth recorders (M-STDs), bathythermographs (BTs), expendable bathythermographs (XBTs)

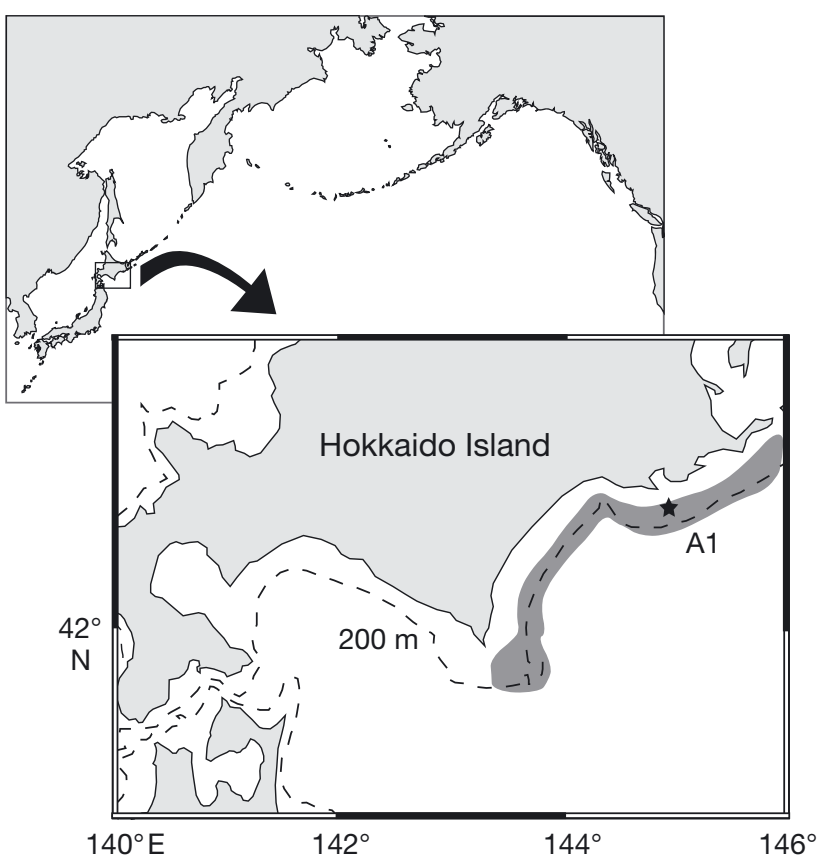

Fig. 1. Sample collection area (dark grey) relative to the North Pacific Ocean. The position of the A1 monitoring station is also shown 
Table 1. Theragra chalcogramma. Number of specimens whose stomachs were analyzed in the present study sampled during spring and summer (March-August) and during autumn and winter (September-February) by different types of gear: RBT = bottom trawls operated by research vessels, RMT = midwater trawls operated by research vessels, LHF $=$ line and hook fishing operated by research vessels, $\mathrm{CBT}=$ bottom trawl operated by commercial vessels, and GN = gillnet operated by commercial vessels

\begin{tabular}{|c|c|c|c|c|c|c|c|c|c|c|}
\hline & \multicolumn{5}{|c|}{$\longrightarrow$ Summer } & \multirow[b]{2}{*}{ RBT } & \multirow{2}{*}{$\overline{\mathrm{RMT}}$} & \multirow{2}{*}{$\begin{array}{l}\text { Winter } \\
\text { LHF }\end{array}$} & \multirow[b]{2}{*}{ CBT } & \multirow[b]{2}{*}{ GN } \\
\hline & RBT & RMT & LHF & CBT & GN & & & & & \\
\hline 1989 & 107 & - & - & - & - & - & - & - & - & - \\
\hline 1990 & 159 & - & - & - & - & - & - & - & - & - \\
\hline 1991 & 171 & - & - & - & - & - & - & - & - & - \\
\hline 1992 & 184 & - & - & - & - & - & - & - & - & - \\
\hline 1995 & - & 128 & 22 & - & - & - & 266 & - & 40 & - \\
\hline 1996 & 20 & 447 & 33 & 69 & - & 70 & 218 & - & - & - \\
\hline 1997 & 397 & 167 & & 98 & - & 420 & 253 & 14 & 336 & - \\
\hline 1998 & 267 & 119 & 29 & 30 & - & 193 & 323 & - & 85 & 30 \\
\hline 1999 & 185 & 16 & - & - & 66 & 779 & 51 & - & 26 & 199 \\
\hline 2000 & 343 & - & 14 & - & - & 753 & - & - & - & - \\
\hline 2001 & 323 & 185 & - & - & - & - & - & - & - & - \\
\hline 2002 & 326 & 86 & - & - & - & 500 & - & - & - & - \\
\hline 2003 & 255 & 130 & - & - & - & 488 & 85 & - & - & - \\
\hline 2004 & 542 & 286 & - & - & - & 372 & 148 & - & - & - \\
\hline 2005 & 269 & 277 & - & - & - & 31 & - & - & - & - \\
\hline 2006 & 842 & 175 & - & - & - & 258 & - & - & - & - \\
\hline 2007 & 409 & 134 & - & - & - & - & 155 & - & - & - \\
\hline 2008 & 392 & 422 & - & - & - & - & - & - & - & - \\
\hline 2009 & 165 & 322 & - & - & - & - & - & - & - & - \\
\hline 2010 & 121 & 232 & - & - & - & - & - & - & - & - \\
\hline 2011 & 186 & 239 & - & - & - & - & - & - & - & - \\
\hline
\end{tabular}

ket specimens measured between 1990 and 2009. In the Doto area, the body condition of pollock decreases throughout winter, and then recovers abruptly during May (Yamamura et al. 2002), whereas maturation begins in November (Tsuji 1990). Therefore, we used data for market pollock landed between June and October to calculate the condition factor (CF) for each $100 \mathrm{~mm}$ body size class (i.e. 201-300, 301-400, 401-500 mm) and year as $\mathrm{CF}=\mathrm{BW} / \mathrm{SL}^{3} \times 10^{6}$, where BW and SL are body weight $(g)$ and standard length (mm), respectively.

\section{Data analysis}

Data were divided into subsamples based on year, season and body size class. Based on

or expendable CTDs. Fish were measured and weighed either on board or in the laboratory to the nearest $1 \mathrm{~mm}$ and $1 \mathrm{~g}$, respectively. They were then dissected, and their stomachs were removed and fixed in a $10 \%$ formalin seawater solution.

\section{Diet analysis}

In the laboratory, stomachs were cut open in a Petri dish filled with water, and the contents were removed from the stomach and pylorus. The stomach contents were placed on filter paper, and the excess water was removed by suction. The contents were then sorted and identified to the lowest taxon possible, under a stereoscopic microscope. Each item of stomach contents was dried separately in a drying oven at $52^{\circ} \mathrm{C}$ for $24 \mathrm{~h}$ and in a desiccator for 36 to $48 \mathrm{~h}$, and then weighed to the nearest $1 \mathrm{mg}$. Fish diets were assessed based on dry weight composition (\% DW).

\section{Fish condition}

To explore the interannual difference in the nutritional condition of pollock, condition factors were calculated using lengths and weights for 26098 mar- sampling date and length, specimens were divided into 2 seasonal groups: spring and summer (from March to August, hereafter 'summer'), and autumn and winter (from September to February, hereafter 'winter') and 3 body size classes (BSC): small ( $\leq 300 \mathrm{~mm} \mathrm{SL})$, intermediate (301-400 mm SL) and large (>400 mm SL). Dietary composition was calculated for each combination of year, season and BSC, hereafter referred to as 'subsamples'. A total of 4 subsamples (55 individuals), each of which comprised $<20$ individuals, was removed from the analysis due to the limited sample sizes. For the description of diets, prey items were grouped into 11 categories, which were further divided into 23 taxonomic/ ecological groups for numerical analyses (Table 2).

To compare fish diets among different subsamples, we calculated percent similarity (PS): $\mathrm{PS}=1-$ $0.5 \sum\left|p_{i}-q_{i}\right|$, where $p_{i}$ and $q_{i}$ are the DW contribution of the ith prey category in subsamples $p$ and $q$, respectively (Schoener 1970). Using the PS matrices, subsamples were classified by hierarchical cluster analysis with complete linkage algorithm to determine the level of variation among different years and BSCs. The cluster analysis was run separately for subsamples from summer $(\mathrm{N}=62)$ and winter $(\mathrm{N}=$ 33). The PS matrix was also used to test for differences in diets by BSC, season and climate period. 
Table 2. Theragra chalcogramma. Groupings of prey categories for general description and numerical analysis

\begin{tabular}{|c|c|}
\hline $\begin{array}{l}\text { Category for general } \\
\text { description }\end{array}$ & $\begin{array}{l}\text { Group for numerical } \\
\text { analysis }\end{array}$ \\
\hline Copepods & Copepods \\
\hline Euphausiids & Euphausiids \\
\hline Hyperiids & Hyperiids \\
\hline Appendicularia & Appendicularia \\
\hline Other zooplankton & $\begin{array}{l}\text { Chaetognath, fish larvae, } \\
\text { decapod larvae, pelagic } \\
\text { annelids, pelagic gastropods }\end{array}$ \\
\hline Mesopelagic squids & Watasenia scintillans, gonatiids \\
\hline Mesopelagic fishes & $\begin{array}{l}\text { Myctophids, other mesopelagic } \\
\text { fishes }\end{array}$ \\
\hline Pollock & Pollock \\
\hline Anchovy & Anchovy \\
\hline Small benthos & $\begin{array}{l}\text { Gammarids, Cumacea, crango- } \\
\text { niids, other decapod crus- } \\
\text { taceans, other small benthos }\end{array}$ \\
\hline Others & $\begin{array}{l}\text { Mesopelagic shrimps, Colorabis } \\
\text { saira, scavenged leftovers of } \\
\text { squid prey items }\end{array}$ \\
\hline
\end{tabular}

A 3-factor permutational multivariate analysis of variance (PERMANOVA) was performed using the ADONIS function available in the 'vegan' package for $\mathrm{R}$ (Oksanen et al. 2011). PS was also calculated for specimens sampled by the different trawl net towing methods (bottom and midwater), BSCs, seasons and year periods to account for the biases due to the towing methods. To obtain sufficient number of specimens for the comparison, data from 1989 to 2000 and from 2001 to 2011 were pooled. However, PS was not calculated for large BSC fish sampled during winter because the number of fish sampled by midwater trawl was limited (62 and 82 individuals for the 1989-2000 and 2001-2011 periods, respectively).

Redundancy analysis (RDA) was applied to diets aggregated by subsample. RDA is an ordination technique extending principal component analysis to explain the variation in a set of response variables (diet composition) using another matrix of environmental parameters (ter Braak 1995). The environmental parameters included in the RDA were fishing depth, water temperature at the fishing depth, year and date. Sampling dates were expressed as days since March 1, the starting date of the summer period in the present study. The significance of the ordination axis was tested by Monte Carlo permutation based on 199 iterations. These analyses were performed using the 'vegan' community ecology package for R (Oksanen et al. 2011).

\section{RESULTS}

The climate regime shifts in the Oyashio area have been more apparent in the southern (Tohoku) region (Ishizaki 2007), but some signs of climate variation were detected in the bottom layer of the northern region of the Oyashio area (Fig. 2). Winter (January) temperatures in the bottom layer of the A1 monitoring station off the southeastern coast of Hokkaido Island (bottom depth = 91 m; Fig. 1) showed a declining trend rather than discontinuous shifts (Temperature $=-0.077 \times$ year $\left.+156.3, \mathrm{R}^{2}=-0.305, \mathrm{p}=0.014\right)$. During spring (May), elevated temperatures were observed in 1999 and 2000 at the A1 station, resulting in high average temperature for the 1998 to 2002 period $\left(2.33^{\circ} \mathrm{C}\right)$. The other 3 years showed near or below average temperatures $\left(0.2\right.$ to $\left.1.78^{\circ} \mathrm{C}\right)$.

\section{Interannual variation in diets}

Increasing trends (i.e. progessively later in the season) were found in the average sampling date for the summer BSCs over time. The differences in average sampling date between the first (1989) and last (2011) years of the study period were calculated by linear regressions to be 33, 43 and 39 days for small, intermediate and large BSCs, respectively (Fig. 3a). The annual average depth of summer samples showed a trend toward shallow depths over time (Fig. 3b). The average water temperature at the sampling depths generally ranged from 1.5 to $4.0^{\circ} \mathrm{C}$ (Fig. 3c). In spite of the later sampling date and shallower sampling depth in recent years, there was no trend in water temperature.

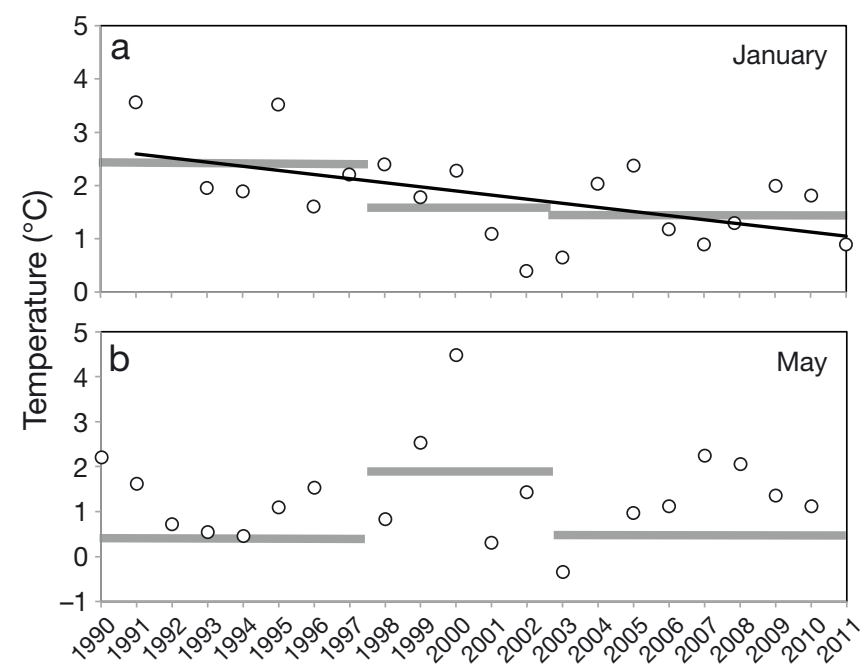

Fig. 2. Time series of water temperature in the bottom layer (75 or $80 \mathrm{~m}$ depth) at the A1 monitoring station (bottom depth = 91 m; Fig. 1) in (a) January and (b) May 
The small BSC pollock fed mainly on copepods, euphausiids and appendicularians (larvaceans) (Fig. 4). Neocalanus cristatus was the most important copepod, accounting for $46.1 \%$ of identifiable copepod DW in this BSC, followed by $N$. plumchrus/flemingeri and $\mathrm{Me}$ tridia spp. (35.6 and $18.3 \%$ DW, respectively). This species composition was different from that observed in the 1990s (Yamamura et al. 2002), when $N$. cristatus accounted for $92.4 \%$

Fig. 3. Average value of sampling parameters (a) date, (b) depth and (c) temperature weighted by number of specimens, for each subsample representing a different year, season and size class. Sum = spring and summer (March to August), Win = autumn and winter (September to February), $\mathrm{S}=$ small ( $\leq 300 \mathrm{~mm} \mathrm{SL}), \mathrm{M}=$ medium $(301-400 \mathrm{~mm} \mathrm{SL}), \mathrm{L}=$ large (>400 mm SL)

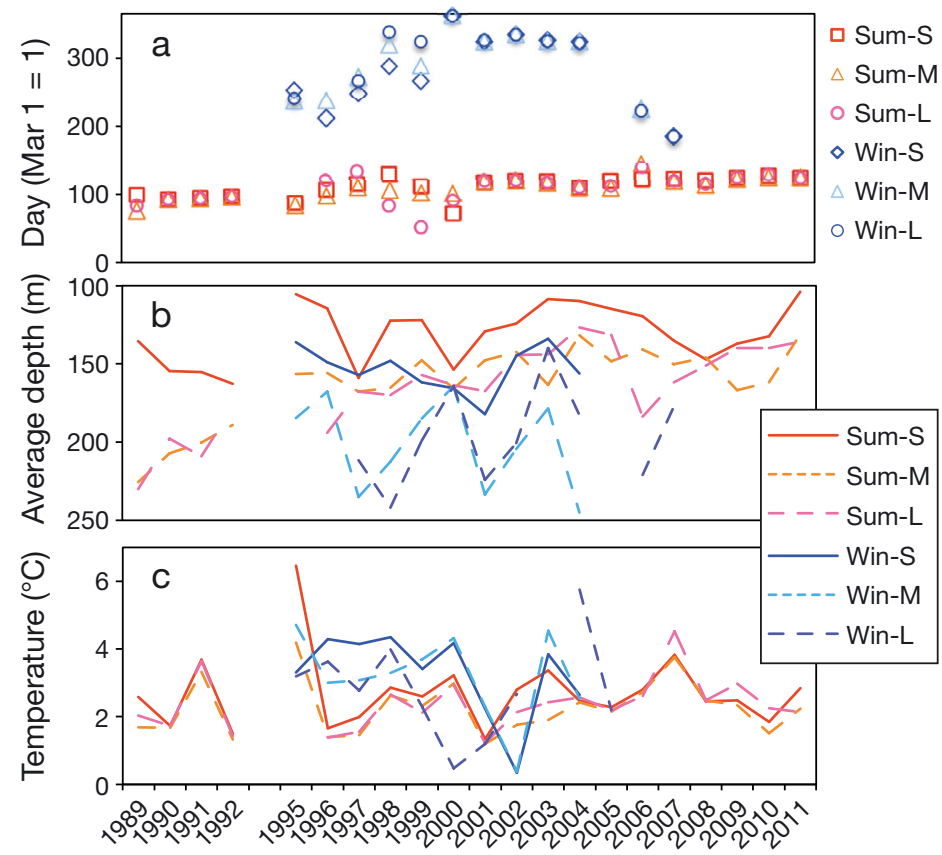

$301-400 \mathrm{~mm} \mathrm{SL}$

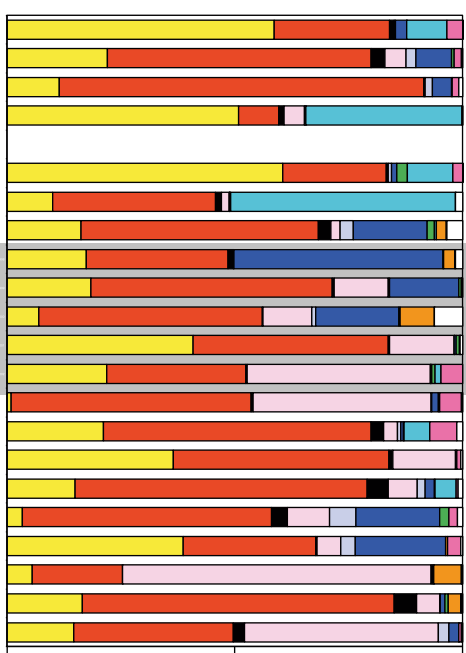

$>400 \mathrm{~mm} \mathrm{SL}$

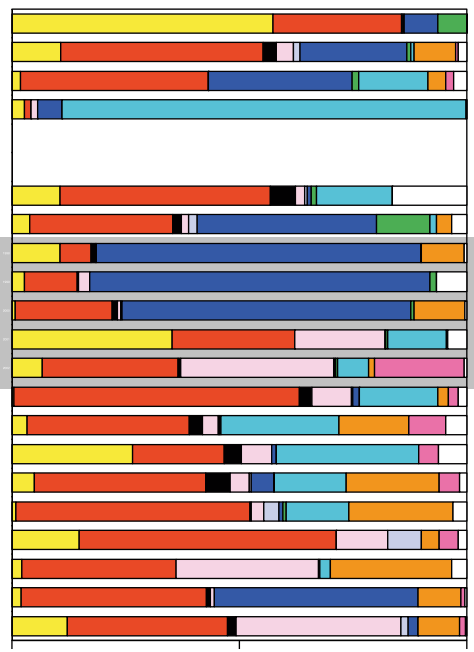

Winter
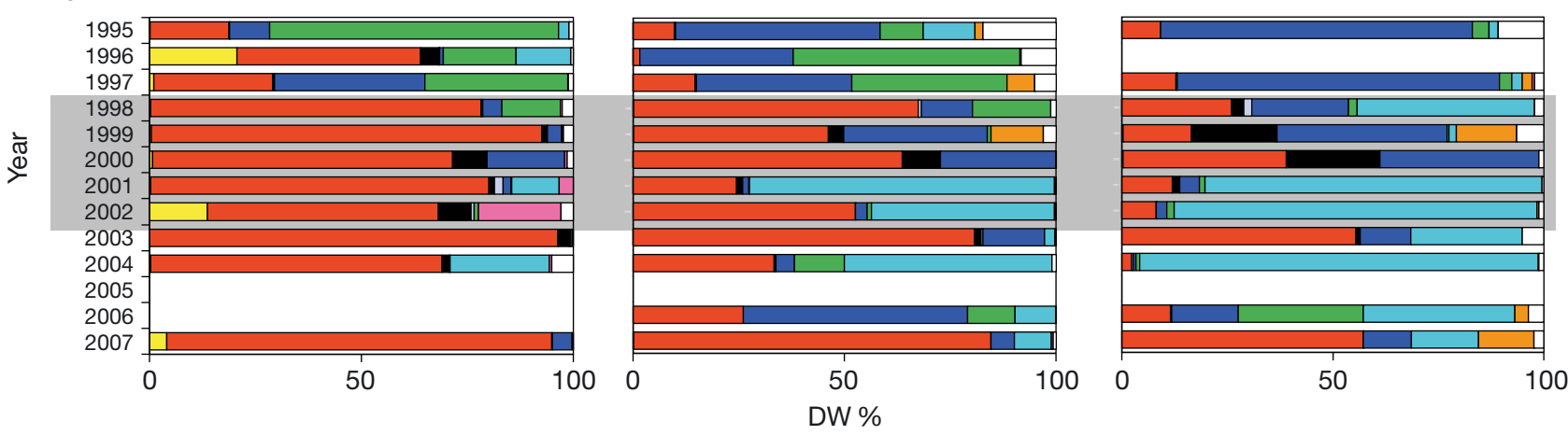

$\square$ Copepods

$\square$ Other zooplankton

$\square$ Anchovy

$\square$ Euphausiids
Mesopelagic fishes
$\square$ Small benthos

- Hyperiids

$\square$ Mesopelagic squids

$\square$ Others

$\square$ Appendicularia

$\square$ Pollock

Fig. 4. Theragra chalcogramma. Interannual variation in diets for spring and summer (upper panels; March to August) and autumn and winter (lower panels; September to February) represented as dry weight composition for different size classes. Gray shaded areas show the years of the 'warm climate period' (1998-2002) 
of the identifiable copepods in the diet of the small BSC. Euphausia pacifica was the most important euphausiid prey, accounting for $66.4 \%$ DW of identifiable euphausiids, followed by Thysanoessa longipes/inspinata $(22.6 \%)$ and T. inermis $(11.1 \%)$. Copepods and euphausiids combined made up $>85 \%$ DW of diets throughout the study period, except in 1996, when cannibalism accounted for $21.6 \%$ DW of the diet. The most prominent interannual change in the diet of small pollock was an increase in consumption of appendicularians, which became important in 1999 and contributed on average $22.1 \%$ of total DW in the diets between 1999 and 2011, contributing $>15 \%$ DW during 10 out of 13 summers.

Although copepods and euphausiids also dominated diets of the intermediate $\mathrm{BSC}$, the importance of small-sized copepod species (Neocalanus plumchurus/flemingeri and Metridia spp.) was substantially lower (2.4 and $0.4 \%$ DW, respectively) than in the small BSC (Fig. 4). Either mesopelagic fishes or cannibalism were also important by 2000 , but were replaced with appendicularians after 2000. In the largest BSC, mesopelagic fishes were the most important prey between 1998 and 2000, whereas cannibalism was important during 1992 and 1996 (similar to the intermediate BSC), and again during 2003 and 2007. Appendicularians became important in 2001 (19.8\% DW), when mesopelagic fishes almost disappeared from the diet.

During winter, all 3 BSCs showed apparent interannual changes in diets (Fig. 4). In the small BSC, mesopelagic fishes (mainly Diaphus theta with body sizes $\leq 60 \mathrm{~mm}$ SL) and squids (mainly firefly squid Watasenia scintillans) were important between 1995 and 1997, whereas euphausiids dominated during other years. Euphausia pacifica dominated diets during autumn and winter, accounting for $96.8 \%$ DW of identifiable euphausiids. Like small BSC pollock, the intermediate BSC mainly consumed mesopelagic fishes and squids in the first 3 years (1995 through 1997), but shifted to euphausiids as the most important prey in the next 3 years (1998 through 2000). After 2001, euphausiids and cannibalism became equally important. The large BSC pollock consumed mainly mesopelagic fishes during the first 5 years (1995 through 2000) except during 1998, when cannibalism was most important (42.1\% DW). Hyperiid amphipod Themisto japonica was also an important prey during 1999 and 2000 (>20\% DW). After 2001, pollock were the most important prey items for the large BSC (i.e. cannibalism) in 4 out of 6 years.

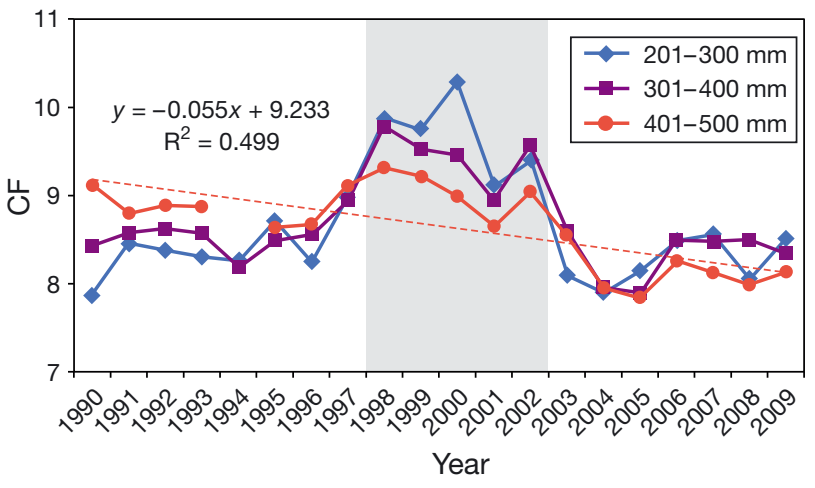

Fig. 5. Theragra chalcogramma. Interannual variation in average condition factor (CF), for different body size classes based on market specimens sampled between May and October. The 401-500 mm SL size class showed a significant decreasing trend over the period $\left(\mathrm{R}^{2}=0.499\right)$. Gray shaded area shows the years of the 'warm period' (1998-2002)

\section{Body condition of fish}

The CF of the small and intermediate BSCs was notably higher during the warm 1998-2002 period compared to the 2 'cool' periods of 1990-1997 and 2003-2009 (Fig. 5). This tendency was more apparent in the small BSC (2-way ANOVA, Table 3). The large BSC showed no significant difference in $\mathrm{CF}$ between the first and second climate periods $\left(1\right.$-way ANOVA $_{i} F=1.94$, df $\left.=11\right)$, but showed a significantly declining trend over the 2 decades $\left(C F=-0.055 \times\right.$ year $\left.+9.233, R^{2}=0.499, p<0.001\right)$. The relationship between $\mathrm{CF}$ and temperature in the bottom layer of the coastal Doto area was explored using the data from the A1 station during January and May (Table 4). Condition was not significantly related to bottom temperatures during January for any size class, but CFs of the small BSC showed a weak but significant positive relationship with temperature during May $\left(\mathrm{R}^{2}=0.254\right.$, $\mathrm{p}<0.05)$.

Table 3. Theragra chalcogramma. Two-way analysis of variance (ANOVA) comparing body condition factor (CF) of walleye pollock among different climate periods and body size classes (BSC)

\begin{tabular}{|lrrrc|}
\hline Factor & df & \multicolumn{1}{c}{ SS } & $F$ & $p$ \\
\hline Period & 2 & 11.962 & 74.297 & $<0.001$ \\
BSC & 2 & 0.149 & 0.925 & 0.4031 \\
Period $\times$ BSC & 4 & 1.990 & 6.181 & $<0.001$ \\
\hline
\end{tabular}


Table 4. Theragra chalcogramma. Linear regression analysis between condition factor $(\mathrm{CF})$ and water temperature in the bottom layer at the A1 monitoring station (Fig. 2) according to body size class (BSC)

\begin{tabular}{|lcccccc|}
\hline Month & BSC $(\mathrm{mm})$ & $a$ & $b$ & $\mathrm{~N}$ & $\mathrm{R}^{2}$ & $\mathrm{p}$ \\
\hline January & $201-300$ & -0.298 & 9.22 & 20 & 0.126 & 0.125 \\
& $301-400$ & -0.180 & 9.03 & 20 & 0.079 & 0.230 \\
\multirow{4}{*}{ May } & $401-500$ & 0.094 & 8.48 & 19 & 0.022 & 0.545 \\
& $201-300$ & 0.256 & 8.25 & 20 & 0.254 & 0.024 \\
& $301-400$ & 0.142 & 8.46 & 20 & 0.135 & 0.111 \\
& $401-500$ & 0.073 & 8.52 & 19 & 0.046 & 0.378 \\
\hline
\end{tabular}

\section{Dietary similarity}

In the cluster analysis of summer diets, subsamples were separated into 2 clusters at the $4 \%$ level of PS, each of which were characterized by ingestion of euphausiids (Cluster A) and copepods (Cluster B) (Fig. 6). These clusters further branched into 4 and 3 trophic subclusters at the $30 \%$ level of PS, respectively. Pollock, appendicularians, mesopelagic fishes and copepods were characteristic prey in addition to euphausiids for the dietary subclusters in Cluster A (subclusters i-iv, Table 5). A subsample in Cluster B (92L), whose diet was almost exclusively cannibalistic,
Table 5. Theragra chalcogramma. Summary of dietary subclusters (see Fig. 6) determined at a $30 \%$ level of percent similarity (PS) in the cluster analysis. Number of subsamples from each climate period and typical prey are given. Ap = appendicularians, $\mathrm{Co}=$ copepods, $\mathrm{Eu}=$ euphausiids, $\mathrm{MF}=$ mesopelagic fishes, $\mathrm{MS}=$ mesopelagic squids, $\mathrm{Po}=$ walleye pollock

\begin{tabular}{|c|c|c|c|c|}
\hline $\begin{array}{l}\text { Dietary } \\
\text { subcluster }\end{array}$ & I & $\begin{array}{l}\text { eriod } \\
\text { II }\end{array}$ & III & $\begin{array}{l}\text { Typical } \\
\text { prey }\end{array}$ \\
\hline \multicolumn{5}{|l|}{ Summer } \\
\hline (i) & 2 & - & 3 & Eu, Po \\
\hline (ii) & - & 2 & 6 & $\mathrm{Ap}, \mathrm{Eu}$ \\
\hline (iii) & 3 & 4 & 1 & $\mathrm{MF}, \mathrm{Eu}$ \\
\hline (iv) & 6 & 5 & 9 & $\mathrm{Eu}, \mathrm{Co}$ \\
\hline (v) & 1 & - & - & Po \\
\hline (vi) & 7 & - & - & $\mathrm{Co}, \mathrm{Eu}$ \\
\hline (vii) & 2 & 3 & 8 & $\mathrm{Co}, \mathrm{Eu}, \mathrm{Ap}$ \\
\hline \multicolumn{5}{|l|}{ Winter } \\
\hline (1) & 2 & 4 & 4 & $\mathrm{Eu}$ \\
\hline (2) & - & 4 & 1 & Eu MF \\
\hline (3) & - & 5 & 3 & $\mathrm{Po}, \mathrm{Eu}$ \\
\hline (4) & 4 & - & - & MS, MF \\
\hline (5) & 3 & 2 & - & MF, Eu \\
\hline
\end{tabular}

was unclassified with other subsamples. The 2 summer subclusters in Cluster B fed mainly on euphausiids (vi) and euphausiids and appendicularians (vii) in addition to copepods. Of the 7 subclusters, (i), (v) and

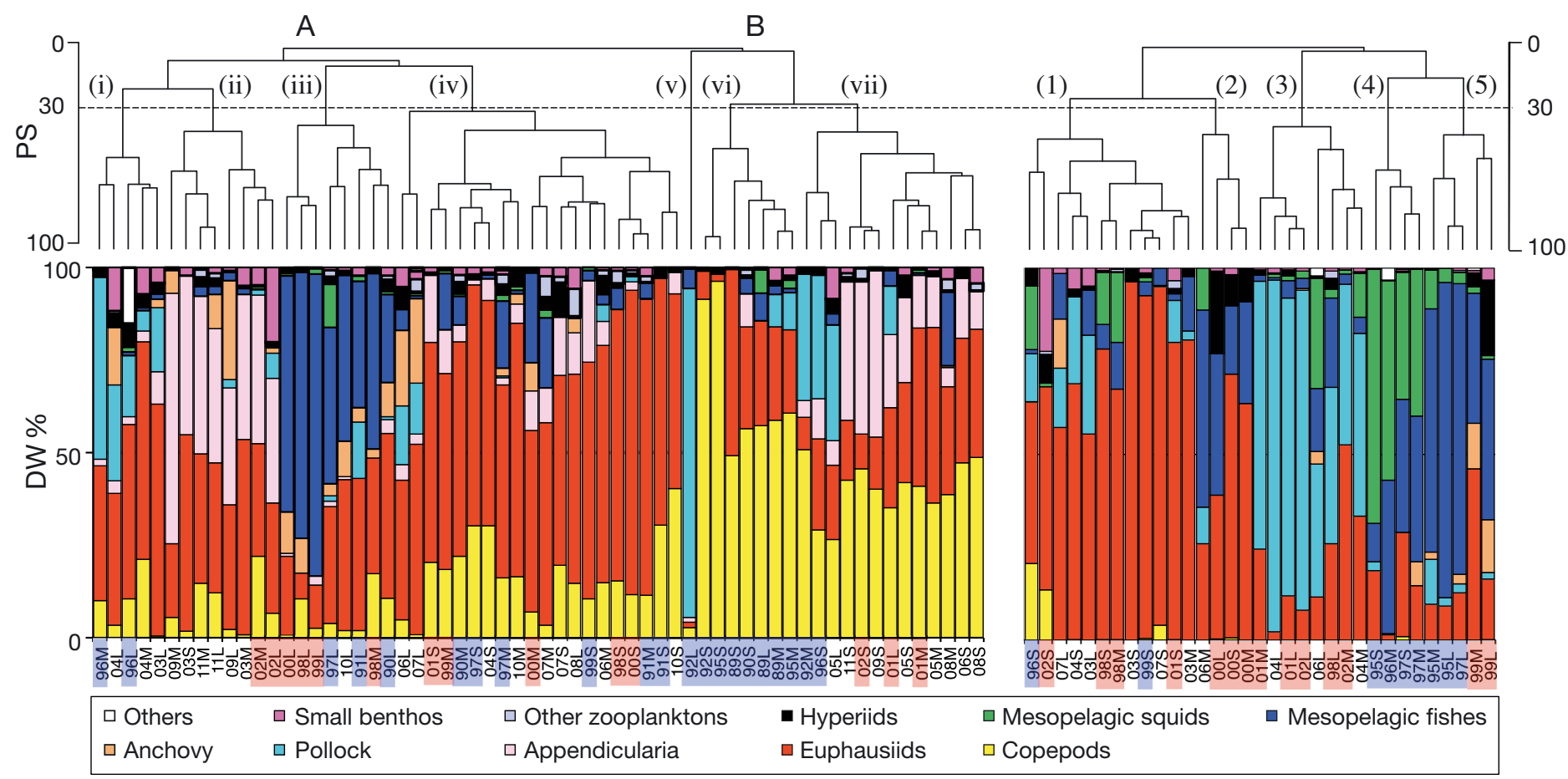

Fig. 6. Theragra chalcogramma. Dendrogram showing dietary similarity (percent similarity; PS) among subsamples representing different years, seasons and fish body size classes (upper) and dry weight composition of diet for each subsample during summer (left) and winter (right). $\mathrm{S}=<300 \mathrm{~mm} \mathrm{SL}, \mathrm{M}=301-400 \mathrm{~mm} \mathrm{SL}, \mathrm{L}=>400 \mathrm{~mm}$ SL. Subsamples from different 'climate periods' are 1989-1997 (blue), 1998-2002 (red), 2003-2007 (white). Note that although PS was calculated based on the 23 categories listed in Table 2, the diets are described based on the 11 categories in this graph. For further explanation of Clusters $\mathrm{A}$ and B, and subclusters (i)-(vii) and (1)-(5) see 'Results: Dietary similarity' and Table 5 
(vi) did not contain subsamples from the warm second climate period. These subclusters were characterized by pollock and copepods in their diets. Subclusters (ii) and (vii), whose diets were characterized by appendicularians, comprised subsamples from the second and third climate periods. Winter subsamples separated into 3 clusters at the $4 \%$ level of PS, each of which fed mainly on euphausiids, pollock and micronekton (mesopelagic squids and fishes). At the $30 \%$ similarity level, 5 winter feeding subclusters were determined. Subcluster (1) comprised subsamples from all 3 climate periods, which had ingested mainly euphausiids. Mesopelagic fishes and euphausiids were characteristic prey in subcluster (2), while subcluster
(3) was characterized by pollock in its diet. These latter 2 subclusters comprised subsamples mainly from the second climate period ( 3 out of 4 , and 5 out of 8 , respectively) with all the rest coming from the third climate period. Subcluster (4) comprised subsamples from the first climate period, whose diets were characterized by mesopelagic squids; mesopelagic fishes were a characteristic prey in subcluster (5).

\section{Dietary difference by towing method}

The similarity in diets between pollock sampled by bottom trawl and midwater trawl was calculated for

Table 6. Theragra chalcogramma. Comparison of diet composition (in DW\%) of walleye pollock from bottom (B) and midwater (Mid) trawl samples. Data were pooled for the first (1989-2000) and second (2001-2011) halves of the study period. Dietary percent similarity (PS) between towing methods is also shown. Note that diet composition was expressed by 10 major prey items, whereas PS was calculated based on the more detailed 25 prey categories given in Table 2 . The items with $>10 \%$ difference in contribution by towing method are indicated as: $\underline{\text { underline }}=$ midwater $<$ bottom; italic $=$ midwater $>$ bottom; ${ }^{\prime}+{ }^{\prime}=<0.1 \%$; ${ }^{\prime}{ }^{\prime}=$ not found; na $=$ not applicable

\begin{tabular}{|c|c|c|c|c|c|c|c|c|c|c|c|c|}
\hline $\begin{array}{l}\text { Size class } \\
\text { Period }\end{array}$ & Trawl & $\begin{array}{l}\text { Cope- } \\
\text { pods }\end{array}$ & Euphausiids & Hyperiids & $\begin{array}{l}\text { Appendi- } \\
\text { cularia }\end{array}$ & $\begin{array}{l}\text { Other } \\
\text { zoo- } \\
\text { plankton }\end{array}$ & $\begin{array}{l}\text { Meso- } \\
\text { pelagic } \\
\text { fishes }\end{array}$ & $\begin{array}{l}\text { Meso- } \\
\text { pelagic } \\
\text { squids }\end{array}$ & Pollock & Anchovy & $\begin{array}{c}\text { Small } \\
\text { benthos }\end{array}$ & PS \\
\hline \multicolumn{13}{|c|}{ Summer (March-August) } \\
\hline \multicolumn{13}{|c|}{$\leq 300 \mathrm{~mm}$} \\
\hline \multirow[t]{2}{*}{ 1989-2000 } & B & 38.0 & 52.4 & 0.7 & 4.3 & 0.7 & 2.5 & 0.1 & 0.2 & - & 0.3 & \multirow{2}{*}{79.5} \\
\hline & Mid & 31.5 & 41.9 & 1.2 & 7.8 & 1.8 & 0.1 & - & 14.9 & - & 0.5 & \\
\hline \multirow[t]{2}{*}{$2001-2011$} & B & 30.1 & $\underline{44.2}$ & 2.2 & 21.3 & 0.6 & 0.0 & 0.1 & - & - & 1.0 & \multirow{2}{*}{82.8} \\
\hline & Mid & 44.7 & 28.9 & 1.5 & 22.8 & 0.1 & 0.3 & 0.0 & _- & - & 0.8 & \\
\hline \multicolumn{13}{|l|}{$301-400 \mathrm{~mm}$} \\
\hline \multirow[t]{2}{*}{ 1989-2000 } & B & 23.1 & $\underline{47.2}$ & 1.2 & 4.5 & 0.9 & 13.6 & 0.3 & 2.4 & 3.4 & 0.6 & \multirow{2}{*}{63.8} \\
\hline & Mid & 13.6 & 33.5 & 0.3 & 2.8 & 1.7 & 10 & 1.5 & 34.1 & - & 0.5 & \\
\hline \multirow[t]{2}{*}{$2001-2011$} & B & 18.1 & $\underline{54.8}$ & 2.2 & 15.2 & 1.4 & 2.7 & 0.4 & 1.6 & + & 2.7 & \multirow{2}{*}{70.7} \\
\hline & Mid & 24.7 & $\overline{31.8}$ & 1.3 & 33.8 & 0.7 & 4.0 & 0.2 & 0.8 & 2.2 & 0.3 & \\
\hline \multicolumn{13}{|l|}{$>400 \mathrm{~mm}$} \\
\hline \multirow[t]{2}{*}{$1989-2000$} & B & 4.4 & 19.6 & 0.6 & 1.5 & 0.3 & 35.8 & 0.8 & $\underline{31.4}$ & 3.4 & 0.3 & \multirow{2}{*}{63.3} \\
\hline & Mid & 1.2 & 27.9 & 0.4 & 3.4 & 2.3 & 28 & 17.6 & 14.0 & 0 & 0.1 & \\
\hline 2001-2011 & B & 10.1 & 41.1 & 2.5 & 15.7 & 0.6 & 1.9 & 0.3 & 14.5 & 4.7 & 5.9 & \multirow{2}{*}{74.8} \\
\hline & Mid & 19.1 & $\overline{27.2}$ & 1.9 & 10.6 & 0.3 & 4.3 & - & 16 & 15.7 & 3.0 & \\
\hline \multicolumn{13}{|l|}{ Overall } \\
\hline & B & 14.1 & 39.0 & 1.6 & 9.5 & 0.7 & 13.9 & 0.5 & 13.7 & 2.8 & 2.3 & \multirow{2}{*}{81.} \\
\hline & Mid & 21.3 & 30.9 & 1.2 & 16.2 & 1.0 & 7.4 & 2.4 & 12.9 & 4.1 & 1.0 & \\
\hline \multicolumn{13}{|c|}{ Winter (September-February) } \\
\hline \multicolumn{13}{|c|}{$\leq 300 \mathrm{~mm}$} \\
\hline 1989-2000 & $\mathrm{B}$ & 1.4 & 75.4 & 2.8 & - & 0.4 & 9 & 8.0 & 0.0 & - & 0.4 & \multirow[b]{2}{*}{68.4} \\
\hline & Mid & 8.7 & 52.1 & 1.9 & - & $\underline{0.3}$ & 6.0 & 23.9 & 5.3 & - & + & \\
\hline \multirow[t]{2}{*}{ 2001-2011 } & B & 1.0 & 78.1 & 2.2 & - & $\overline{0.3}$ & 0 & 0.2 & $\underline{13.2}$ & - & 2.2 & \multirow{2}{*}{80.1} \\
\hline & Mid & 3.9 & 91.0 & 0.1 & - & 0.2 & 4 & 0.0 & $\overline{-}$ & - & + & \\
\hline \multicolumn{13}{|l|}{$301-400 \mathrm{~mm}$} \\
\hline 1989-2000 & B & 0 & $\underline{40.1}$ & 3.7 & - & 0.3 & 23.7 & 16.9 & - & 13.1 & + & \multirow{2}{*}{59.7} \\
\hline & Mid & 0 & 26.2 & 0.1 & - & 0.2 & 45.5 & 8.0 & 4.4 & - & + & \\
\hline 2001-2011 & B & 0 & 48.1 & 0.9 & - & 0.1 & 9.0 & 3.5 & 37.8 & - & 0.1 & \\
\hline & Mid & 0.1 & 58.7 & 0.1 & - & 0.2 & 5.1 & 5.3 & 29.8 & - & 0.2 & 82.6 \\
\hline$>400 \mathrm{~mm}$ & & & & & & & & & & & & \\
\hline 1989-2000 & $B$ & 0.1 & 24.9 & 13.5 & - & 0.5 & 27.6 & 6.5 & 3.1 & 16.1 & + & na \\
\hline & Mid & & & & & Ins & afficient $\mathrm{d}$ & & & & & \\
\hline 2001-2011 & B & - & 15.9 & 0.5 & - & 0.1 & 6.3 & 6.4 & 64.2 & 4.4 & 0.2 & na \\
\hline Overall $(\leq 400$ & $\begin{array}{l}\text { Mld } \\
\mathrm{nm})\end{array}$ & & & & & & 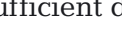 & & & & & \\
\hline & $\mathrm{B}$ & 0.3 & 52.2 & 2.3 & - & 0.3 & 13.4 & 8.5 & 16.6 & 4.5 & 0.3 & \\
\hline & Mid & 2.9 & 53.5 & 0.5 & - & 0.2 & 19.0 & 9.2 & 8.8 & 0.0 & 0.1 & 81.4 \\
\hline
\end{tabular}


different subsets representing different size classes, periods and seasons. The PS index ranged from 59.7 to $82.8 \%$, and the overall similarity during summer and winter was 81.9 and $81.4 \%$, respectively (Table 6). In summer, euphausiids were more dominant in bottom trawled pollock samples, whereas copepods and appendicularians were more important in midwater trawled samples. Cannibalism showed no clear pattern in summer, but was more important in bottom trawl samples during winter.

\section{Source of dietary variation}

All of the 3 sources of dietary variation tested by the PERMANOVA (BSC, climate period and season) were significant $(\mathrm{p}<0.001$; Table 7$)$ with season and BSC accounting for 16.3 and $11.4 \%$ of the total variation, respectively. Climate period explained $7.3 \%$ of the total variation, whereas its interaction with season explained an equivalent fraction of the total variation $(7.3 \%)$. Two-factor PERMANOVA was also performed to explore the interaction term (Table 8). Climate periods accounted for 11.3 and $22.0 \%$ of the total variation during summer and winter, respectively, indicating that the effect of climate period was more pronounced in winter diets.

\section{Ordination}

A tri-plot of subsamples on the first 2 axes of an RDA shows RDA scores of prey items and vectors indicating relative strength and direction of maximum change of constraining (environmental) variables together with sample RDA scores (Fig. 7). In this diagram, the projection of prey categories onto

Table 7. Theragra chalcogramma. Three-factor permutational multivariate analysis of variance (PERMANOVA) comparing dietary composition among different body size classes (BSC), seasons and climate periods

\begin{tabular}{|lrrcc|}
\hline Variables & df & Pseudo-F & $\mathrm{R}^{2}$ & $\mathrm{p}$ \\
\hline BSC & 2 & 9.532 & 0.120 & $<0.001$ \\
Season & 1 & 25.445 & 0.161 & $<0.001$ \\
Period & 2 & 4.733 & 0.060 & $<0.001$ \\
BSC: Season & 2 & 3.073 & 0.039 & $<0.01$ \\
BSC: Period & 4 & 1.256 & 0.032 & 0.204 \\
Season: Period & 2 & 5.929 & 0.075 & $<0.001$ \\
BSC: Season: Period & 4 & 1.113 & 0.028 & 0.330 \\
Residuals & 77 & & 0.486 & \\
\hline
\end{tabular}

Table 8. Theragra chalcogramma. Two-factor permutational multivariate analysis of variance (PERMANOVA) comparing dietary composition among different body size classes (BSC) and climate periods for summer and winter

\begin{tabular}{|lrccc|}
\hline Variables & df & $F$ & $\mathrm{R}^{2}$ & $\mathrm{p}$ \\
\hline Summer & & & & \\
BSC & 2 & 6.707 & 0.166 & 0.001 \\
Period & 2 & 4.666 & 0.116 & 0.001 \\
BSC: Period & 4 & 1.215 & 0.060 & 0.398 \\
Residuals & 53 & & 0.658 & \\
Winter & & & & \\
BSC & 2 & 5.571 & 0.216 & 0.001 \\
Period & 2 & 6.014 & 0.233 & 0.001 \\
BSC: Period & 4 & 1.126 & 0.057 & 0.351 \\
Residuals & 24 & & 0.464 & \\
\hline
\end{tabular}

an arrow approximates the average value of the corresponding variable across samples, weighted by the proportions of the prey in each sample (ter Braak 1995). The permutation test for the RDA showed that a significant portion of the variability in prey composition could be attributed to the constraining variables $(\mathrm{df}=4, F=5.811, \mathrm{p}=0.001)$. The subsamples showed a strong seasonal partitioning along the first axis; winter subsamples were mostly located on the positive segment of the first RDA, whereas the small and intermediate BSCs were located on the negative segment. However, subsamples corresponding to the large BSC from both summer and winter were spread widely along the first axis. Another constraining parameter showing high variance along the first axis was depth, but the effect of depth is difficult to separate from seasonal effects because of the high correlation between these variables, evident in the small angle between the corresponding arrows (ter Braak 1995). The distribution of the large BSC along the first axis is interpreted as a preference by large pollock for deeper waters as winter progresses, with mesopelagic fishes and squids and cannibalism becoming more important in the diet. While the small and intermediate BSCs showed less variation along the first axis of RDA, they showed wider variations along the second axis. Temperature and year were positively and negatively associated with this axis, respectively, implying a trend from relatively high temperatures in early years (Fig. 7, lower quadrants) to low temperatures in later years (upper quadrants). This trend was associated with a shift in the diet of the large BSC from micronekton (mesopelagic fishes and Watasenia scintillans, lower right quadrant in Fig. 7) toward cannibalism (upper right), and from copepods (lower left) toward appendicularians (upper left). 


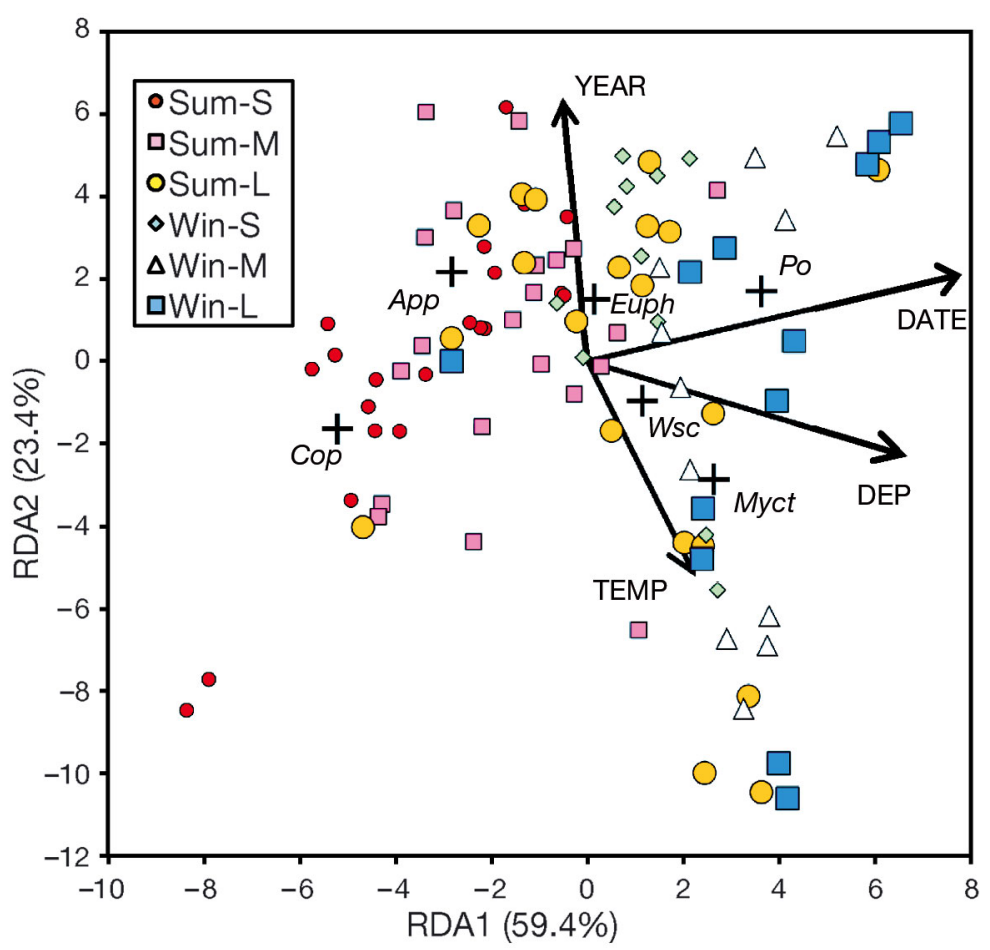

Fig. 7. Theragra chalcogramma. The first 2 axes of redundancy analysis (RDA) for dietary composition of subsamples; species are represented by points, environmental variables by vectors. Sum $=$ spring and summer (March-August), Win = autumn and winter (September-February); $\mathrm{S}=$ $<300 \mathrm{~mm} \mathrm{SL}, \mathrm{M}=301-400 \mathrm{~mm} \mathrm{SL}, \mathrm{L}=>400 \mathrm{~mm}$ SL. Major prey items are shown by ' + ': $A p p=$ appendicularians, $C o p=$ copepods, Euph = euphausiids, Myct $=$ myctophids, WsC $=$ Watasenia scintillans, $P o=$ walleye pollock . The arrows of the explanatory variables indicate the direction of maximum change of these variables across the diagram: TEMP $=$ temperature, DEP = depth, DATE $=$ day of year transformed as Mar $1=1$. The projection of prey categories onto an arrow gives an approximation of their weighted averages with respect to the variable

\section{DISCUSSION}

\section{Source of variations in diets}

Although it is suggested that climate regime shifts occurred in the Doto area between 1998 and 1999, and between 2002 and 2003 (Kasai \& Ono 2007, Overland et al. 2008), there are no clear impacts of these shifts on pollock diets. The greatest shift in pollock diet occurred either between 2000 and 2001 or between 2001 and 2002 (Fig. 4) and was associated with an increase in the consumption of pollock (i.e. cannibalism), appendicularians and anchovy, and a decrease in the consumption of copepods and micronekton. Like other gadid species, pollock are opportunistic feeders, whose diet is primarily determined by the relative abundance of ambient prey and the predator:prey size relationship (Yamamura 2004). Thus, the interannual variation in pollock diets revealed in this study may be attributable to changes in the availability of different prey items in the Doto area. However, other factors such as changes in the average date and depth of summer sampling may have contributed to the observed dietary shifts. The greatest portion of our samples (>80\%) was collected during acoustic surveys, and the primary purpose of these tows was to identify the backscattering observed by echosounders. Because the towing method (bottom or midwater) and the depth of each tow were chosen to target layers where pollock density was highest, changes in sampling depth and an increase in the proportion of midwater trawls is likely to reflect a change in the depth distribution of pollock rather than a sampling bias.

The average sampling date for each BSC shifted forward by 33 to $43 \mathrm{~d}$ over the $23 \mathrm{yr}$ study period. These shifts were from late April (1989) to late May or early June (2011), and could have affected diets to some extent. Similarly, sampling depths for the intermediate and large BSCs during summer decreased over the study period. However, given that the interannual shifts in dietary compositions were abrupt rather than gradual (Fig. 4), the effect of the delay in sampling date on our results seems very limited. Although no apparent trend was found in average temperature in the sampling layers (Fig. 3c), the orientation of the year and temperature vectors in the RDA plot (Fig. 7) implies that these parameters are negatively correlated (ter Braak 1995). Therefore, the interannual variations in diets are likely related to the cooling trend in the coastal Oyashio area, especially during winter (Fig. 2).

\section{Changes in major prey}

In the classification of summer diets, all of the subsamples comprising subcluster (vi) (Fig. 6), which represent copepod diet, were from the first climate period, confirming that copepods were the typical prey for this period. Immediately after the onset of the second climate period in 1998, a steep decline was found in the dietary contribution of copepods, primarily Neocalanus cristatus. We hypothesize that this reflects a negative response of this cold-water prey species to the onset of the second period warm 
conditions. However, no immediate rise in water temperatures was observed in either the sampling layer or at the A1 station. This inconsistency may reflects the fact that Neocalanus copepods are passively transported for a long distance through their life history, and their abundance reflects environmental conditions over a wider (transoceanic) scale rather than on a regional scale (Tatebe et al. 2010). During May, juvenile pollock in the Doto area generally recover their body condition from winter thinning by ingesting $N$. cristatus (Yamamura et al. 2002). Although the standing stock of mesozooplankton during spring (April to June) before and after the 1997-1998 regime shift remained identical in the Oyashio region (Kasai \& Ono 2007), it decreased by $<50 \%$ in summer (July and August). This decrease would have had an adverse effect on food availability for juvenile pollock.

Appendicularians were the representative summer prey for juveniles after the onset of the second climate period in 1998 (Fig. 6). In fact, all of the subsamples comprising subcluster (ii), which represent an appendicularian diet, were from the second and third climate periods. The utilization of appendicularians by pollock has also been reported from the Gulf of Alaska and Bering Sea (Dwyer et al. 1987, Wilson et al. 2011), but appendicularian gravimetric contributions have remained supplemental $(<10 \%)$ in these areas. In the Doto area, their contribution also remained below $2 \%$ DW in the 1990s, even in the small BSC $(\leq 200 \mathrm{~mm}$ SL) (Yamamura et al. 2002). Appendicularians were not identified to species level in the present study, but the major species occurring in the Oyashio region (e.g. Fritillaria borealis and Oikopleura labradoriensis) are generally distributed in the oceanic upper $100 \mathrm{~m}$ layer (Shiga 1985, Tomita et al. 2003). Therefore, pollock containing appendicularians in their stomachs probably consumed them in shallow layers $(\leq 100 \mathrm{~m})$ and benefitted from higher growth rates in the warm surface layer. Appendicularians are ubiquitous in the Oyashio area, but their dominance in the total biomass of mesozooplakton is generally low $(<1 \%)$ (Shinada et al. 2001, Ikeda et al. 2008). They were ingested by pollock along with their mucous house, which is used to retain suspended particles in the water column (Flood 2003). This fact, along with the extremely high production rate of appendicularians (Sato et al. 2001), suggests that their ingestion provides an alternative trophic pathway from primary production to pollock.

Mesopelagic fish comprising mainly myctophids Daiphus theta was also an important prey category showing steep declines in the diets of intermediate and larger pollock BSCs. They almost disappeared from the diets during summer and winter 2001, $3 \mathrm{yr}$ after the onset of the warm climate period. Because over $99 \%$ of $D$. theta in the Doto area are age $\leq 3$ (Ivanov \& Lapko 1994, Yamamura \& Yasuma 2010), we hypothesize that this species failed to reproduce in the warm environment during and after 1998. We further speculate that the 1997 cohort disappeared from the Doto area and became unavailable to pollock after reaching age 4 . Unfortunately, we have no time series data on the abundance of $D$. theta, but this species has the potential to be strongly affected by climate variation, since it inhabits the surface layer of the Oyashio-Kuroshio transition area and therefore experiences greater environmental variations during its early life stages than in the Oyashio area (Moku et al. 2003, Yasuda 2003). Thus, the disappearance of $D$. theta from the diets of pollock after 2000 suggests an interesting example of the delayed effects of an environmental event on higher trophic levels.

Prey items that increased in pollock diets after the disappearance of myctophids were juvenile pollock and anchovy. In the 1990s, the incidence of heavy cannibalism was limited to the spring period in the Doto area (Yamamura et al. 2001) — because strong stratification during summer and autumn offered juveniles thermal barriers against cannibalistic adults, and mesopelagic fishes and squids were important prey during winter (Yamamura et al. 2002). The increased winter cannibalism observed in this study compensated for the lack of mesopelagic fishes and squids, which were absent from diets between 2001 and 2005. However, some sign of relief from winter cannibalism was observed during 2006 and 2007, suggesting that mesopelagic fishes recovered enough to again become an important prey for larger pollock.

Anchovy became an important summer prey for the large BSC after 2006. Anchovy distributed off the Pacific coast of Japan have stayed at a relatively high and stable stock level ( $>0.5$ million $\mathrm{t}$ ) after the collapse of sardines in the early 1990s (Yatsu et al. 2010). Anchovy is a warm water species, which is distributed also in the Oyashio area during summer and autumn. Their distribution is generally limited to the surface layer $(\sim 20 \mathrm{~m})$, but they are occasionally found at deeper depths ( 100 m) (Ohshimo \& Hamatsu 1996). The chances that large-sized pollock, which generally reside in deeper waters, encounter anchovy seem very limited, and thus the gradual increase of anchovy in the diet during recent years may reflect decreased abundance or availability of alternative prey. 


\section{Variation in condition}

In the Doto area, pollock condition decreases from late autumn through winter and then recovers rapidly during May (Kooka et al. 2009, Kooka \& Yamamura 2012). Their main prey during spring is Neocalanus cristatus, which may be the key prey for pollock to recover from winter condition (Yamamura et al. 2002). Therefore, the decrease of copepods (especially Neocalanus cristatus) in pollock diets after 1998 was expected to adversely affect the nutritional condition of juvenile pollock. However, in spite of the potential importance of copepods for recovery, CF increased rapidly in 1998 when the proportion of copepods in the diet decreased, especially in the small BSC. We suggest that the increase in $\mathrm{CF}$ was attributable to the bioenergetic response of pollock to warmer temperatures. In laboratory experiments, juvenile pollock (112-153 mm fork length) exhibited maximal food ingestion and growth rate at $12.3^{\circ} \mathrm{C}$ and $11.5^{\circ} \mathrm{C}$, respectively, while growth (conversion) efficiency remained relatively stable between 2 and $9^{\circ} \mathrm{C}$ (Kooka et al. 2007). These results indicate that pollock (especially juveniles) benefit nutritionally from a warmer environment as long as sufficient food is available. However, average temperatures at the depths where pollock were sampled were not significantly different between climate periods or between BSCs (2-way ANOVA, Table 9). This inconsistency may be partly due to differences in the vertical distribution of pollock between day and night. Pollock, especially at younger ages, are typically distributed in the warm surface layers during night and twilight (Brodeur et al. 2000, Miyashita et al. 2004). However, trawl sampling was conducted during the day, when pollock were distributed in deeper and cooler layers. The observed increase in $\mathrm{CF}$ was maximal in the small, and minimal in the large BSCs (Fig. 5), consistent with a decrease in the optimal temperature for growth with increasing body weight (Morita et al. 2010). Only the largest BSC showed a decreasing trend in body condition through the $20 \mathrm{yr}$ studied. We have no plausible explanation for this decrease, but the cooling trend in

Table 9. Theragra chalcogramma. Two-way analysis of variance (ANOVA) comparing habitat temperature among different climate periods and body size classes (BSC)

\begin{tabular}{|lcccc|}
\hline Factor & df & SS & $F$ & $p$ \\
\hline Period & 2 & 1.248 & 0.713 & 0.495 \\
BSC & 2 & 1.424 & 1.386 & 0.259 \\
Period $\times$ BSC & 4 & 1.277 & 0.365 & 0.833 \\
\hline
\end{tabular}

the bottom layer of the coastal Doto area during winter (Fig. 2) may be partly responsible. The low temperature in the Doto coastal area during winter is caused mainly by the outflow of East Sakhalin Current water from the southern Okhotsk Sea (Oguma et al. 2008); hence, the decreasing trend in pollock condition could be associated with water mass dynamics upstream of the Oyashio current.

\section{Implication for population dynamics}

Variations in the incidence of cannibalism directly affect the population dynamics of pollock. Cannibalism in the Doto area in the 1990s has been reported to be density dependent, with age 1 pollock cannibalized more heavily in a year following strong recruitment. With more recent data added, the contribution of cannibalism to the diets of larger pollock (>300 mm SL) still showed a significant correlation with a reproductive success index (i.e. estimated number of recruits in a given year divided by spawning stock biomass) (Mori et al. 2012) in the previous year $\left(\mathrm{R}^{2}=0.213, \mathrm{n}=21, \mathrm{p}<0.05\right.$; Fig. 8). Thus, summer cannibalism was more prevalent after a year with high recruitment, implying the potential to dampen interannual variations in recruitment (Yamamura et al. 2001), whereas winter cannibalism showed only a non-significant negative correlation with recruitment.

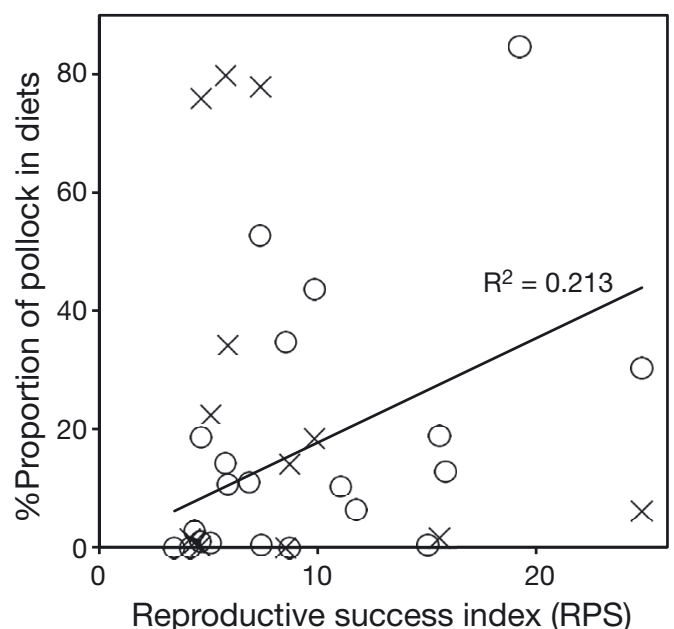

Fig. 8. Theragra chalcogramma. Relationship between reproductive success index (recruitment per spawning: RPS) of the Japan Pacific population of walleye pollock and incidence of cannibalism during the first winter after settlement (age $0 ;$ ) and summer of the following year (age $1 ; \times$ ). Only summer cannibalism showed a significant positive correlation between RPS in the preceding year $\left(\mathrm{R}^{2}=0.213, \mathrm{~N}=\right.$ $21, \mathrm{p}<0.05)$ 
While the dietary shift immediately after the onset of the warm period in 1998 was less pronounced for smaller pollock (small and intermediate BSC), a rapid increase in body condition was observed after 1998, perhaps reflecting a bioenergetic response to the warm environment. This response differed from that in the Eastern Bering Sea (EBS), where the decreased abundance of large mesozooplankton during a warm period (2002 to 2005) resulted in reduced body condition and poor survival of age 0 pollock during the subsequent winter (Coyle et al. 2011, Hunt et al. 2011). Starvation mortality of juvenile pollock was quite unlikely in the Doto area even during the 2003 winter, when energy content and body condition were low (Kooka et al. 2009, Kooka \& Yamamura 2012). Virtually no juveniles with severely depleted lipid levels were present, and averagesized juveniles in March 2004 had energy reserves allowing for a $105 \mathrm{~d}$ period without food before starving to death. Further study is needed to elucidate why such a difference occurs in response to the climate impact by area, although it may partially be explained by topography. Food depletion is likely in years of poor prey production in the EBS because the wide continental shelf $(>500 \mathrm{~km}$ ) (Stabeno et al. 1999) prevents the advective supply of prey from the outer shelf (Napp et al. 2000, Ciannelli et al. 2002), whereas a relatively narrow $(<30 \mathrm{~km})$ continental shelf makes it easy for offshore prey to be advected into the coastal area (Tatebe et al. 2010). Juvenile pollock in the Doto area are capable of accessing the outer-shelf production, although more predation risk is expected in deeper waters (Yamamura \& Nobetsu 2012). Thus, pollock in the Doto area have flexible feeding habits to cope with environmental variability by utilizing a wide range of prey items and habitats.

Acknowledgements. Foremost, we are grateful to all of the people who participated or helped with sample collection at sea: T. Hattori, T. Hamatsu, K. Yabuki, K. Watanabe, O. Shida and M. Chimura; crews and officers of the FRVs 'Tanshu-maru', 'Wakataka-maru', 'Kaiyo-maru', 'Hokuho-maru', 'Torishima', 'Kaiyo-maru 3', 'Kaiyo-maru 5', 'Hokko-maru', 'Yutaka' and 'Kaiyo-maru 7'. We thank F. Mueter and anonymous reviewers for greatly improving the quality of the manuscript; T. Azumaya, T. Ikeda, T. Kobari, K. Kooka, H. Kuroda, M. Moku, H. Saito, Y. Sakurai, N. Shiga, and A. Tsuda for their helpful discussions. This study would have been impossible without the dedicated assistance of $\mathrm{M}$. Ishiguro in the laboratory.

\section{LITERATURE CITED}

Bailey KM, Powers DM, Quattro JM, Villa G, Nishimura A, Traynor JJ, Walters G (1999) Population ecology and structural dynamics of walleye pollock (Theragra chalco- gramma). In: Loughlin TR, Ohtani K (eds) Dynamics of the Bering Sea. University of Alaska Grant, Fairbanks, AK, p 581-614

> Brodeur RD, Wilson MT, Ciannelli L (2000) Spatial and temporal variability in feeding and condition of age- 0 walleye pollock (Theragra chalcogramma) in frontal regions of the Bering Sea. ICES J Mar Sci 57:256-264

Chiba S, Aita MN, Tadokoro K, Saino T, Sugisaki H, Nakata K (2008) From climate regime shifts to lower-trophic level phenology: synthesis of recent progress in retrospective studies of the western North Pacific. Prog Oceanogr 77:112-126

- Ciannelli L, Brodeur RD, Swartzman GL, Salo S (2002) Physical and biological factors influencing the spatial distribution of age-0 walleye pollock (Theragra chalcogramma) around the Pribilof Islands, Bering Sea. Deep-Sea Res II 49:6109-6126

> Ciannelli L, Brodeur R, Napp J (2004) Foraging impact on zooplankton by age-0 walleye pollock (Theragra chalcogramma) around a front in the southeast Bering Sea. Mar Biol 144:515-526

- Coyle KO, Eisner LB, Mueter FJ, Pinchuk AI and others (2011) Climate change in the southeastern Bering Sea: impacts on pollock stocks and implications for the oscillating control hypothesis. Fish Oceanogr 20:139-156

Dwyer DA, Bailey KM, Livingston PA (1987) Feeding habits and daily ration of walleye pollock (Theragra chalcogramma) in the eastern Bering Sea, with special reference to cannibalism. Can J Fish Aquat Sci 44:1972-1984

FAO (2009) Fisheries resources: trends in production, utilization and trade. In: Grainger R (ed) The state of world fisheries and aquaculture 2008. FAO, Rome, p 3-84

Flood PR (2003) House formation and feeding behaviour of Fritillaria borealis (Appendicularia: Tunicata). Mar Biol 143:467-475

Gorbatenko KM, Dolganova NT (1989) Feeding of sexually mature walleye pollock, Theragra chalcogramma, and utilization of the food resources in the Okhotsk Sea during autumn. J Ichthyol 29:138-145

> Hare SR, Mantua NJ (2000) Empirical evidence for North Pacific regime shifts in 1977 and 1989. Prog Oceanogr 47:103-145

> Hunt GL, Coyle KO, Eisner LB, Farley EV and others (2011) Climate impacts on eastern Bering Sea foodwebs: a synthesis of new data and an assessment of the Oscillating Control Hypothesis. ICES J Mar Sci 68:1230-1243

> Ikeda T, Shiga N, Yamaguchi A (2008) Structure, biomass distribution and trophodynamics of the pelagic ecosystem in the Oyashio region, western subarctic Pacific. J Oceanogr 64:339-354

Ishizaki S (2007) The state of the western North Pacific in the first half of 2006. PICES Press 15:24-26

Ishizaki S (2011) The state of the western North Pacific in the second half of 2010. PICES Press 19:33-34

Ivanov OA, Lapko VV (1994) Size and age characteristics of the mesopelagic fish Diaphus theta (myctophidae) in the south Krile region. Russ J Mar Biol 20:148-152

- Kasai H, Ono T (2007) Has the 1998 regime shift also occurred in the oceanographic conditions and lower trophic ecosystem of the Oyashio region? J Oceanogr 63:661-669

> Kooka K, Yamamura O (2012) Winter energy allocation and deficit of juvenile walleye pollock Theragra chalcogramma in the Doto area, northern Japan. Environ Biol Fishes 94:389-402

> Kooka K, Yamamura O, Nishimura A, Hamatsu T, Yanagimoto T (2007) Optimum temperature for growth of juvenile walleye pollock Theragra chalcogramma. J Exp Mar 
Biol Ecol 347:69-76

Kooka K, Yamamura O, Ohkubo N, Honda S (2009) Winter lipid depletion of juvenile walleye pollock Theragra chalcogramma in the Doto area, northern Japan. J Fish Biol 75:186-202

Miyashita K, Tetsumura K, Honda S, Oshima T, Kawabe R, Sasaki K (2004) Diet changes in vertical distribution patterns of zooplankton and walleye pollock (Theragra chalcogramma) off the Pacific coast of eastern Hokkaido, Japan estimated by the volume back scattering strength (Sv) difference method. Fish Oceanogr 13:99-110

Moku M, Tsuda A, Kawaguchi K (2003) Spawning season and migration of the myctophid fish Diaphus theta in the western North Pacific. Ichthyol Res 50:52-58

Mori K, Funamoto T, Yamashita Y, Chimura M (2012) Stock assessment and evaluation for Japanese Pacific stock of walleye pollock (fiscal year 2011). In: Marine fisheries stock assessment and evaluation for Japanese waters (fiscal year 2011/2012). Fisheries Agency and Fisheries Research Agency of Japan, Tokyo, p 419-467 (in Japanese)

Morita K, Fukuwaka M, Tanimata N, Yamamura O (2010) Size-dependent thermal preferences in a pelagic fish. Oikos 119:1265-1272

> Mueter FJ, Ladd C, Palmer MC, Norcross BL (2006) Bottomup and top-down controls of walleye pollock (Theragra chalcogramma) on the Eastern Bering Sea shelf. Prog Oceanogr 68:152-183

Napp JM, Kendall AW, Schumacher JD (2000) A synthesis of biological and physical processes affecting the feeding environment of larval walleye pollock (Theragra chalcogramma) in the eastern Bering Sea. Fish Oceanogr 9: $147-162$

> Oguma S, Ono T, Kusaka A, Kasai H, Kawasaki Y, Azumaya $\mathrm{T}$ (2008) Isotopic tracers for water masses in the coastal region of eastern Hokkaido. J Oceanogr 64:525-539

Ohshimo S, Hamatsu T (1996) Vertical distribution and acoustic estimation of biomass of walleye pollock Theragra chalcogramma, and anchovy Engraulis japonicus in the Pacific coast of eastern Hokkaido. Bull Hokkaido Natl Fish Res Inst 60:225-237

Okamoto S, Hirawake T, Saitoh SI (2010) Interannual variability in the magnitude and timing of the spring bloom in the Oyashio region. Deep-Sea Res II 57:1608-1617

Oksanen J, Blanchet FG, Kindt R, Legendre P and others (2011) Community ecology package 'vegan'. In R package version 2.15.0, http://CRAN.R-project.org/package=vegan

> Overland J, Rodionov S, Minobe S, Bond N (2008) North Pacific regime shifts: definitions, issues and recent transitions. Prog Oceanogr 77:92-102

Sakurai Y (2007) An overview of the Oyashio ecosystem. Deep-Sea Res II 54:2526-2542

Sato R, Tanaka Y, Ishimaru T (2001) House production by Oikopleura dioica (Tunicata, Appendicularia) under laboratory conditions. J Plankton Res 23:415-423

Schoener TW (1970) Non-synchronous spatial overlap of lizards in patchy habitats. Ecology 51:408-418

Shiga N (1985) Seasonal and vertical distributions of appendicularia in Volcano Bay, Hokkaido, Japan. Bull Mar Sci $37: 425-439$

> Shinada A, Ikeda T, Ban S, Tsuda A (2001) Seasonal dynamics of planktonic food chain in the Oyashio region, western subarctic Pacific. J Plankton Res 23:1237-1247

Springer AM (1992) A review: Walleye pollock in the North Pacific-How much difference do they really make? Fish Oceanogr 1:80-96
Stabeno PJ, Schumacher JD, Ohtani K (1999) The physical oceanography of the Bering Sea. In: Loughlin TR, Ohtani $\mathrm{K}$ (eds) Dynamics of the Bering Sea. University of Alaska Sea Grant, Fairbanks, AK, p 1-28

Tadokoro K, Ono T, Yasuda I, Osafune S, Shiomoto A, Sugisaki H (2009) Possible mechanisms of decadal-scale variation in $\mathrm{PO}_{4}$ concentration in the western North Pacific. Geophys Res Lett 36:L08606, doi:10.1029/2009GL037327

Tamura T, Fujise Y, Shimazaki K (1998) Diet of minke whales Balaenoptera acutorostrata in the northwestern part of North Pacific in summer 1994 and 1995. Fish Sci 64:71-76

Taniguchi A (1999) Differences in the structure of the lower trophic levels of pelagic ecosystems in the eastem and western subarctic Pacific. Prog Oceanogr 43:289-315

> Tatebe H, Yasuda I, Saito H, Shimizu Y (2010) Horizontal transport of the calanoid copepod Neocalanus in the North Pacific: the influences of the current system and the life history. Deep-Sea Res I 57:409-419

ter Braak C (1995) Ordination. In: Jongman R, ter Braak C, van Tongeren $\mathrm{O}$ (eds) Data analysis in community and landscape ecology. Cambridge University Press, Cambridge, p 91-173

> Tomita M, Shiga N, Ikeda T (2003) Seasonal occurrence and vertical distribution of appendicularians in Toyama Bay, southern Japan Sea. J Plankton Res 25:579-589

Tsuji S (1990) Alaska pollock population, Theragra chalcogramma, of Japan and its adjacent waters, II: Reproductive ecology and problems in population studies. Mar Behav Physiol 16:61-107

> Wilson MT, Jump CM, Buchheister A (2009) Ecology of small neritic fishes in the western Gulf of Alaska. II. Consumption of krill in relation to krill standing stock and the physical environment. Mar Ecol Prog Ser 392:239-251

Wilson MT, Buchheister A, Jump C (2011) Regional variation in the annual feeding cycle of juvenile walleye pollock (Theragra chalcogramma) in the western Gulf of Alaska. Fish Bull 109:316-326

Yamamura O (2004) Trophodynamic modeling of walleye pollock in the Doto area, northern Japan: model description and baseline simulations. Fish Oceanogr 13(Suppl 1):138-154

Yamamura O, Nobetsu T (2012) Food habits of threadfin hakeling Laemonema longipes along the Pacific coast of northern Japan. J Mar Biol Assoc UK 92:613-621

Yamamura O, Yasuma H (2010) Macrozooplankton and micronekton off Hokkaido Island, Japan: composition and gear inter-calibration. In: Pakhomov E, Yamamura O (eds) Report of the advisory panel on micronekton sampling inter-calibration experiment. PICES Sci Rep 38: 37-50

> Yamamura O, Yabuki K, Shida O, Watanabe K, Honda S (2001) Spring cannibalism on 1 year walleye pollock in the Doto area, northern Japan: Is it density dependent? J Fish Biol 59:645-656

> Yamamura O, Honda S, Shida O, Hamatsu T (2002) Diets of walleye pollock Theragra chalcogramma in the Doto area, northern Japan: ontogenetic and seasonal variations. Mar Ecol Prog Ser 238:187-198

> Yasuda I (2003) Hydrographic structure and variability in the Kuroshio-Oyashio Transition Area. J Oceanogr 59: 389-402

Yatsu A, Yamashita N, Watanabe Y (2010) Pelagic fish and squid. In: McKinnell SM, Dagg MJ (eds) Marine ecosystems of the North Pacific Ocean, 2003-2008. PICES Spec Pub 4:320-325

Submitted: December 8, 2011; Accepted: June 11, 2013

Proofs received from author(s): September 10, 2013 